6. Серошесвкий В.Л. Якуты: опыт этнографического исследования [Текст]/В.Л. Серощевский// - Москва, 1993.

7. Тайлор, Э. Б. Первобытная культура [Текст] / Э.Б. Тайлор / Пер. с англ. - М.: Политиздат, 1989. - С.466. - 573c. 18

8. Фрэзер, Дж. Дж. Золотая ветвь: Исследование магии и религии [Текст] / Дж. Дж. Фрэзер; [пер. с анг. М. К. Рыклина]. - М.: Эскмо, 2006. - 960 с. 21

9. НА РС(Я). - Фонд Якутского краеведческого музея им. Ярославского.

10. НА РС(Я) - Ф.1413. - ОП.2. - Д.49-53. Личный фонд И.Д. Новгородова

11. ПМА. Мегино- Кангаласский улус, с. Балыктах. Год. 2015

12. ПМА - Экспедиция Исторического Факультета «Социокультурная трансформация современного якутского села», с.Балыктах, Мегино-Кангаласский район Республики Саха (Якутия), июль 2015, июнь 2016.

\title{
Сильные и слабые стороны в области страхования в сфере туризма
}

\author{
Виноградов Е.С., аспирант, \\ Санкт-Петербургский государственный экономический университет, \\ 2. Санкт-Петербург \\ E-mail: yagrswip@mail.ru
}

\section{Научный руководитель: к.с.н., доцент Печерица Е.В.}

Для выявления основных проблем и сильных сторон в области страхования в сфере туризма, необходимо разъяснить: что же, все-таки, такое - страхование в туризме. В покрытие по данному виду страхования входят не только защита имущественных интересов туристов или же туроператоров, а также трудоспособности и жизни в целом, но далеко не в малой степени и со здоровьем, что позволяет отнести данный вид к добровольному медицинскому страхованию (ДМС). Некоторые экономисты считают, что этот вид относится больше к личному страхованию от несчастных случаев. Наряду с этим существуют и другие эксперты, которые, в свою очередь, абстрагируют данный вид в совершенно иной, отдельный от всех остальных вид страхования. Помимо уже названных видов защиты в данной группе страхования существует также страхование ответственности туроператоров и туристов, поэтому данный вид невозможно отнести ни к одному другому. Он выделяется из всех своей обширностью рисков и покрытий [6,7].

В конце 2015 года была принята на рассмотрение новая редакция закона «Об основах туристской деятельности в Российской Федерации». Согласно данной редакции российские путешественники будут обязаны страховаться (или же турфирмы будут обязательно включать в турпакет страховой полис) $[1,8]$.

Необходимость развития такого вида страхования, как туристское страхование в первую очередь необходима для обеспечения гарантированно качественной защитой за пределами своего государства, а также предоставление финансовых гарантий, что в современном мире катастрофически важно. В безопасности туристов всего мира, т.е. граждан любой страны, заинтересованы все без исключения: сами туристы, органы 
государственной власти как для выезжающих, так и для въезжающих путешественников, а также различные туристические организации [9].

Роль страхования в сфере туризма также является основополагающей в развитии национального рынка страхования:

- Расширение границ взаимодействий страхователей и страховщиков, а также укрепление доверительных отношений.

- Массовость страхования приводит к расширению уже существующего рынка сбыта страховых услуг и закреплению его позиций в целом.

- Развитие комбинированных видов страхования таких, как туристское страхование является основной перспективой на рынке страховых услуг.

Определение всевозможных рисков в области туризма также является основным способом защиты туристов. Уже существующие риски представлены в таблицах 1 и 2 в приложении. Так, например, остро стоящие в последнее время вопросы о рисках терроризма или диверсии практически не страхуется страховыми компаниями, однако для этого создаются специальные организации [2].

Современным страховым компаниям не выгодно заниматься антитеррористическим страхованием, потому что этот вид страхования несет огромные убытки. Так, например, теракт 11 сентября 2001 года принес убытки в размере около 32,5 миллиардов долларов, что в 2010 году составило бы около 40 миллиардов долларов.

Россия по уровню развития страхования отстает от экономически развитых стран Запада. Так, по отношению к валовому продукту доля собираемых страховых платежей в западных странах в среднем 7,6\%. В наиболее экономически развитых он составляет от 9,5 до 12,3\%, иногда достигает и 16,5\%. В России же - лишь 2,35\%. На душу населения на Западе приходится в среднем 2,5 тысяч долларов страховых взносов. У нас - примерно 267 долларов. Это в 35 раз меньше, чем в Швейцарии, в 25 раз меньше, чем в США и даже в два раза меньше, чем в Польше.

Основную долю страховых премий на Западе дает долгосрочное страхование жизни. А огромные размеры аккумулированных компаниями страхования жизни резервов премий представляют собой средства для инвестиций. У нас же львиная доля премий поступает от краткосрочных видов страхования: имущественного, страхования от несчастных случаев и добровольного медицинского страхования, включая и страхование в туризме. А страхование жизни, в отличие от Запада, не дает и 3\% поступлений.

На нашем рынке так же, как и на Западе, происходит процесс концентрации и централизации капитала, образуются монополии. Сегодня можно наблюдать тенденцию сокращения количества страховых компаний, как на российском рынке, так и на западном. На данный момент в России осталось всего 367 страховых компаний, однако 10 из этих 367 компаний имеют 80\% всех страховых сборов в стране. То есть 2,7\% страховых компаний занимают $80 \%$ рынка.

Таблица 1

Количество действующих страховых компаний по годам

\begin{tabular}{|l|c|c|c|c|c|}
\hline Год & 1994 & 2001 & 2007 & 2011 & 2016 \\
\hline Количество & 2028 & 980 & 890 & 585 & 325 \\
\hline
\end{tabular}


Таким образом, наглядно видно превращение в монопольный рынок с ограниченным количеством страховых компаний. Данное явление поддерживается и продвигается органами страхового надзора, которые с каждым годом повышают требования к уставному капиталу. В результате наблюдается резкий спад количества страховых компаний за небольшой промежуток времени [3].

Размер уставного капитала прописан в законе РФ от 27.11.1992 N 4015-1 (ред. от 28.11.2015) "Об организации страхового дела в Российской Федерации": «минимальный размер уставного капитала страховщика, осуществляющего исключительно медицинское страхование, устанавливается в сумме 60 миллионов рублей. Минимальный размер уставного капитала иного страховщика определяется на основе базового размера его уставного капитала, равного 120 миллионам рублей, и различных коэффициентов» [4].

Возможно, действия по увеличению уставного капитала страховых компаний нашими надзорными органами отчасти оправданы, поскольку повышение размера собственных средств компаний (а уставные капиталы - огромная часть собственных средств) необходимо для обеспечения финансовой стабильности и платежеспособности страховщиков. Так, в Западных странах требуют, чтобы уставные капиталы страховых компаний составлял более $20 \%$ в отношении к сумме поступающих средств. Для нашего рынка такие условия, по мнению страхового надзора, в данный момент невозможны. По мнению экспертов, при таких условиях 65\% компаний попросту не выживут [5].

Рынок страховых услуг за рубежом имеет большую историю, где обширное развитие получило направление туристского страхования. Постоянный обзор, анализ и сопоставление национального рынка страхования России и рынков зарубежных стран должны способствовать развитию рынка туристического страхования.

На данном этапе развития укрепляются тенденции экономического роста значимости и универсализации деятельности страховых компаний. В отличие от нашего рынка, на зарубежном рынке страхования присутствуют такие компании, которые по большей части занимаются страхованием в туризме, как туристских организаций, так и самих туристов. Узкая специализация страховых компаний обуславливает уровень страховых услуг на более высоком уровне, нежели компании, занимающиеся всеми видами страхования. Однако эти страховые компании занимают далеко не лидирующие позиции на рынке. С другой стороны, аналитические способности страховых компаний с небольшим разнообразием видов страхования, более качественно подходят к вопросу оценки рисков в данной области, что благоприятно сказывается как на результатах данной компании, так и в развитии всего рынка туристического страхования.

Развитый рынок страховых услуг за рубежом является отличным примером для развития собственного национального рынка страхования. На примере зарубежного опыта есть возможность создавать специализированные страховые туристские компании для полноценной и качественной защиты страхователей. Возможно внедрение изменений в страховой рынок, чтобы страховые компании страховали не по лицензируемым видам страхования, а по секторам экономики или сферам деятельности, что позволит более детально углубляться в проблемы существующих рисков. В России уже существует ряд таких компаний. Одним из примеров таких компаний является крупная страховая компания «СОГАЗ». Данная страховая компания 
в основном занимается страхованием компании по добыче и переработки нефти и газа - компании «Газпром».

Список литературы:

1. Всероссийский союз страховщиков [сайт] URL: www.ins-union.ru (Дата обращения 15.01.2016).

2. Черникова Л.И., Фейзрахманова Н.М. Современные тенденции страховой защиты интересов туристов в России. Финансовая аналитика: проблемы и решения. 2012. № 29 (119). С. 33-39.

3. Медиа-Информационная Группа «Страхование сегодня» [Электронный pecypc] URL: www.insur-info.ru/register/2016-01 (Дата обращения 13.01.2016).

4. Закон РФ от 27.11.1992 N 4015-1 (ред. от 03.07.2016) "Об организации страхового дела в Российской Федерации" (с изм. и доп., вступ. в силу с 01.01.2017) [Электронный ресурс].

URL: https://www.consultant.ru/document/cons_doc_LAW_1307/0963c136c6685f6420ce2ac0aa1e 7d5fbc1d6816/ (Дата обращения 13.01.16).

5. Страхование XXI века - вызовы современности: сборник научных трудов. Орланюк-Малицкая Л.А., М.: Фин. Ун-т, 2012 72-76с.

6. Artal-Tur A., Romanova G., Del Mar Vazquez-Mendez M., Vapnyarskaya O., Kharitonova T., Ilkevich S., Sakharchuk E., Allen D., Roden S., Sharafanova E., Pecheritsa E., Pulido-Fernandez Ju.I., Ward-Perkins D., Krukova O., Vetitnev A., Keup M., Belosluttseva L., Garcia Sanchez A., Fedulin A. TOURISM IN RUSSIA: A MANAGEMENT HANDBOOK. Bingley, 2015. 426 p.

7. Caldito L.A., Dimanche F., Mazina A., Fedulin A., Vetitnev A., Apukhtin A., Kruzhkov D., Kurbanov E., Pecheritsa E., Sakharchuk E., Sharafanova E., Romanova G., Alexanyanc G., Tatarskikh Iu., Belosluttseva L., Smit N., Kryukova O., Vapnyarskaya O., Ilkevich S., Kharitonova T. et al. TOURISM IN RUSSIA. TEMPUS Project "NETOUR: Network for Excellence in Tourism through Organization and Universities in Russia" / Project Co-funded by the European Union. Spain, 2015. 28 p.

8. Печерица Е.В. Управление туристской отраслью на федеральном, региональном и муниципальном уровнях. Международный научно-исследовательский журнал. 2014. № 1-3 (20). С. 55-56.

9. Печерица Е.В. Позиционирование предприятий индустрии гостеприимства в условиях конкуренции: монография / Е. В. Печерица; Министерство образования и науки Российской Федерации, Федеральное агентство по образованию, СанктПетербургский гос. ун-т сервиса и экономики. Санкт-Петербург, 2010. 163 с. 